\title{
Only Planet: Unsettling Travel, Culture and Climate Change in Settler Australia
}

\author{
Alice Robinson and Dan Tout
}

\section{Droughts and Flooding Rains}

Dorothea Mackellar's infamous flooding rains were absent from the Victorian environment for over a decade, long enough to facilitate the gradual but grudging acceptance amongst the state's inhabitants of their seemingly interminable counterpart: drought. By 2010, we had not personally experienced 'proper' rain since childhood. In absence, even our memories of rain had dimmed; the very idea had been rendered mythological, as abstract as God. We had come to consider Mackellar's description of 'steady, soaking rain' arriving after inevitably temporary periods of drought as nothing more than a literary liberty; an imagined artifice deployed towards the retention of rhyme throughout her patriotic poem rather than a description of actual, observable ecological reality.

Like many Melburnians at this time, we had - at least to a certain extentreconciled (or resigned) ourselves to a continuing lack of water resources and to the prospect of a very dry future. Then, in late 2010, it began to pour; this was not just rain, but the steady, soaking downpours of what had come to appear as nothing more than a fanciful figment of Mackellar's imagination. The exhilaration and optimism we experienced in the wake of these rains is difficult to describe. As young people engaged with climate change discourses, existing in painful awareness of the ecological challenges we all confront, and facing the prospect of a life without sufficient water, our experience of sustained, serious rains was transcendent. For a brief window, we felt hope.

By February 2011, however, large tracts of Victoria and Queensland were under water. The scale of the destruction, so tragically precipitated by the very element we had for so long coveted and even prayed for under the haplessly sincere urgings of then Prime Minister Howard ('Pray for Rain, Urges Howard'), was immense. The sense that something 'wasn't right' in our environment began to re-emerge in public discourses with renewed urgency; the realisation that climate change would result in more frequent and extreme instances of both sides of Mackellar's environmental coin was disturbingly revelatory. Despite our culture of forgetfulness, facilitated by the longest period of drought on 
record (Melbourne Water) on the driest inhabited continent on earth (Australian Government Department of Foreign Affairs \& Trade), it turned out Australia was still, after all, a place 'of droughts and flooding rains' (Mackellar).

As the floodwaters began to recede, we found ourselves wondering why Mackellar's observations - representing, as we saw it, the insufficiency of settler Australians' knowledge of 'their' environment - remained inadequately understood, over a century later, by the broader Australian community. Why had the droughts and floods we had just endured come as such an 'unexpected' shock and been described, despite their increasingly frequent and repetitive occurrence, as one-in-one-hundred-year events? We found ourselves wondering whether our contemporary experiences of ecological disaster were merely indicative of natural shifts and cycles, or whether something in our environment was already wrong, changed or in the process of changing? In addressing the second question, we came up against the first: why, we wondered, don't settler Australian cultures know enough about their surrounding environments in order to answer either? Was the answer to be found in Mackellar's location at 'home' in England at the time of writing her patriotic reflection on what she had originally entitled Core of My Heart? That is, does the persistent rite of passage for settler Australians of a journey back to 'the mother country' function as a diversion, a displacement, an escape from the settler experience of unsettlement, or a means of reflecting upon and understanding Australia more accurately from afar?

As we were to discover, the questions we found ourselves asking in the wake of the floods were in many ways not particularly or peculiarly timely or topical at all, but referred to enduring facets of settler Australian relationships to Australian lands - to place, settlement and home - that have simply been rendered increasingly urgent under the imminent threat of climate change. The following comprises an examination and attempted explication of some of the issues and questions this period raises in relation to settler unsettlement, travel and climate change in Australia; in particular, the ways in which the travel habits of settler Australians are intertwined with climate change and its mitigation on the one hand and with Australia's settler-colonial history on the other. It is our suggestion that settler Australians need to settle both physically, by curbing their propensity for air travel and thereby their contribution to anthropogenic climate change, as well as metaphysically, by reconciling with their histories and resolving their as yet unsettled situatedness within settlercolonial Australia. 


\section{Settler Australians}

By settler Australians, we refer to those who experience a sense of what Hage has termed 'governmental belonging' in their relation to the Australian national imaginary; those who see themselves as inhabiting 'what is often referred to as the national will' (45-46). Settlers have been defined by Veracini as 'founders of political orders [who] carry their sovereignty with them' and can be distinguished from migrant populations on the basis that the latter move to 'a political order that is already constituted ... and are characterised by a defining lack of sovereign entitlement'; whereas '[m]igrants... move to another country and lead diasporic lives, settlers... move ... to their country' (Settler Colonialism 3). Yet the boundaries delimiting migrants from the settler population are by no means permanently fixed; the political economy of settler colonialism is 'a dynamic environment where different groups are routinely imagined as transiting from one section of the population system to another' (20). Our conception of a restrictedly dynamic settler Australian population may therefore be conceived as closely resembling Hage's categorisation of 'White Australians', into which migrants may be 'assimilated' through the accumulation of sufficient 'practical nationality', a process nevertheless constrained by an individual's habitus and the limitations imposed upon it by the 'aristocracy of the field' (53-62).

In Australia, the dominant ethnic core of the (settler) nation (Smith) has been historically inhabited by settlers of Anglo-Celtic origins and descent and it is this aristocratic section of the Australian population to which our analysis primarily pertains. Yet beyond this analytically useful categorisation we also acknowledge the complexity and contingency of the settler collective; in adopting the term 'settler Australians', we are not intending to artificially homogenise or render monolithic an inherently dynamic and heterogeneous situation. Rather we are intentionally adopting the taxonomy of settler-colonialism in order to uncover, analyse and thereby problematise the specific structural imperatives and exigencies we conceive as central to the settler Australian experience, perhaps more central to the experiences of settlers of Anglo-Celtic origins than others but of relevance to all those who regard themselves as inhabitants of the settler Australian national imaginary nonetheless. Importantly, as Read has outlined, settler Australians can and do experience a sense of belonging in place (Returning to Nothing; Belonging); our intention here is not to undermine or dismiss these legitimate individual experiences, but to outline what we conceive as the structural barriers against the emergence of a deeper, collective sense of settledness amongst the settler Australian population deriving from Australia's settler-colonial foundations. 


\section{Seeing Double: Unsettled Settlers in Settler Australia}

It is now a commonplace to observe that the doctrine of terra nullius rested not only on the wholesale denial of indigenous knowledges and histories, but derived its most powerful legitimating force through association with Lockean conceptions of property, whereby '[w]hatsoever ... he removes out of the State that Nature hath provided and left it in, he hath mixed his Labour with it, and joined to it something that is his own, and thereby makes it his Property' (Locke 116). In this construction, the fact that 'indigenous peoples did not engage in European style agriculture' meant that 'they did not really own the land, but merely ranged over it' (Lloyd 34).

However, here we wish to emphasise that the 'settlement' of Australia under the Enlightenment ideologies of progress and improvement (Gascoigne) involves a 'double effacement of memory: an effacement of the migratory history of the settler and the effacement of the Aborigines as autochthons' (Garbutt, The Locals, our emphasis). The moment of 'settlement' is constructed by settler society as Year Zero (Rose, Reports From a Wild Country), as the beginning of knowledge (Arthur 54-57) and the beginning of history (45). This is made true for both the coloniser and the colonised; '[t]he experience of colonisation is about beginning again; time does not migrate but remains in the originating country' (45). Australia becomes 'the tabula rasa upon which [the colonising culture] will inscribe its civilisation' (Rose, Reports From a Wild Country 62).

Any intimations of a pre-existing sovereign indigenous presence are, quite literally, washed away with the 'tide of history'; Australia as terra incognita here becomes a terra nullius - literally a 'land belonging to no-one' (Reynolds, The Law of the Land 12). Having disavowed indigenous knowledges, history and sovereignty in preparing the ground for 'settlement' and having inadvertently dislocated and thereby negated their own historicity in the process, the settlers find themselves alone within an empty geographical and historical space; a terranulliusincognita. In this situation, the settler is left with little option but to imagine themselves accepting the 'mantle of belonging to the land' from the indigene as the inevitable outcome of progressive linear history (Rose, Reports From a Wild Country 117) and as the only possibility of escape from an unsettled state of 'historylessness' (Veracini, 'Historylessness').

The notion of replacement - of striving 'for the elimination of the native in favour of an unmediated connection between the settlers and the land' (Veracini Settler Colonialism 272) - constitutes a fundamental, foundational feature of the settler colonial order. In Wolfe's definition, '[s]ettler colonies were (are) premised on the elimination of native societies' (Settler Colonialism 2); unlike 
other forms of colonialism, settler colonisation has as its 'primary object ... the land itself' and is therefore 'a winner-take-all project whose dominant feature is not exploitation but replacement' (163). To the extent that the settler colonial imagination constructs a geographically and historically negated space emerging at the moment of its own inception, this process of elimination and replacement appears relatively straightforward.

Yet the settler promises to be a superior indigene precisely because 'he' brings his history - and with it, 'his' superior knowledge and practices - with him; he can no more efface his own pre-history without undermining his legitimating claims for 'settlement' than he can completely replace the indigene without doing so. Further, the settler is compelled to keep the category of indigene intact in order to (attempt to) inhabit it, yet in the act of emptying it of historical significance to enable its inhabitation he renders it obsolete. The 'founding forgetting' (Garbutt, The Locals 191) required by and for both terra incognita and terra nullius consequently remains always and everywhere incomplete; the very act of founding through attempted elimination and replacement prohibits the possibility of forgetting.

The 'long transitive moment' ushered in by European colonisation may therefore be conceived as presenting 'problems for settlers as well as for Aboriginal people' due to the inevitably unfulfilled 'redemptive purpose' of replacing the indigenous order with a new and improved settler-colonial civilisation (Rose, Reports From a Wild Country 66). Settler indigenisation remains, in Goldie's terms, 'an impossible necessity' (13); an 'important site of conflict' is consequently created for settler societies at the contested point of juncture between 'the backward-looking impotence of exile and the forward-looking impetus to indigeneity' (Ashcroft, Griffiths and Tiffin 135).

Further, the continuing existence of an aboriginal presence-literally, a presence from the origin(Hodge and Mishra 25) - functions constantly and unsettlingly to remind the settler of their status as 'an alien in their own land', initiating a persistent 'separation of belonging' at the core of the settler experience (Garbutt, The Locals 192). It therefore remains the case that in relation to the establishment of the settler order, 'to get in the way all the native has to do is stay at home' (Rose, cited in Wolfe, Settler Colonialism 1). In 'staying at home' — which is to say surviving - Indigenous Australians continually confront settler Australians with not only the reality of settlers' pre-history elsewhere-at 'home' in England, the Default Country (Arthur) - but also with the facticity of the foundational act of violent dispossession. Indigenous Australians consequently constitute a 'maximal threat to [the] legitimacy' of settler Australians by undermining their already insecure sovereign foundations (Hodge and Mishra 25); a sense of illegitimacy exacerbated by settler Australia's continued reliance on the 'legal 
fiction' of terra nullius (Langton, 'Science Fictions') — which the High Court's decision in Mabo No. 2 overturned 'in relation to property but reaffirmed ... in the matter of sovereignty' (Reynolds, 'New Frontiers' 139).

Similarly, the double vision inherent within the settler Australian lexicon leads to a continuing colonial consciousness 'of two places at the same moment', a simultaneous awareness of 'the colonised landscape and the landscape of origin' (Arthur 27). To the extent that this awareness remains a facet of settler existence for 'as long as the colonist remembers that this was a place where the colonist society or individual once was not' (27) - a memory embedded within the language itself - settlers are repeatedly reminded of both their exile and arrival and yet prevented from either escaping the former or ultimately establishing the latter. Settler Australians find themselves haunted by a specifically settlercolonial 'spectre of comparisons'

It is our suggestion that, as a result of these complex and conflicting settlercolonial exigencies and imperatives, settler Australians find themselves existing in an intractable double bind, a permanent state of unsettlement in which they experience 'a filiative and an affiliative connection with "home" ... where "home" is alternatively (or simultaneously) both the "old" and the "new" place' (21) and yet fail to feel at home in either. In facing forwards towards their impossible but necessary indigenisation whilst simultaneously glancing anxiously backwards over their shoulder in an attempt to both draw upon and disavow their pre-historic connection to the Default Country, the settler negates their own knowledge and historicity - along with that of their indigenous Other - and thereby renders themselves unsettled everywhere and settled nowhere, confined within the triangular dialectic between colonial and indigene (Veracini Settler Colonialism). Trapped between the competing imperatives of settler-colonialism, the first 'striving for indigenisation and national autonomy, the other aiming at neo-European replication and the establishment of a "civilised" pattern of life' (21), the imagined, ideal, indigenous-settler society remains 'a society "to come"' (23).

\section{Settler Australia as a Site of Travel and Exile}

Settler Australia is founded on travel. In the aftermath of the initial arrival of Europeans, '[t]housands of people voyaged over 10,000 miles, half the globe, from Northern Europe to the Antipodes' (Sussex xi) and continue to do so today. While the composition and motivations of settler Australia's migratory history are complex, diverse and have varied over time, the nearly 98\% of Australia's current population of non-Indigenous descent 'are either immigrants $(23 \%)$, the children of immigrants $(22 \%)$ or the descendants of fairly recent immigrants 
(the remaining 53\%)' (Jupp 49). Of these, a substantial majority derive from the British Isles and particularly from England (49). Yet in a characteristically dissembling move, the

Australian language of settlement has no language for migration except for those who come after, who are next, who forever embody migration as 'migrants', who come here from 'somewhere else' ... It has no language for a story that keeps the migration of Anglo-Celtic settlers in mind as migrants. (Garbutt, 'Towards an Ethic of Location' 179)

Thus the structural distinction between settlers and migrants on the basis of the former category's sovereign capacity is reinforced through the simultaneous homogenisation of the history of Australian immigration by those we have termed settlers, alongside the historical and linguistic self-effacement of settlers' own migratory history through claims to white autochthony (Garbutt, The Locals). It remains the case that the 'majority of Australians at most points in our history have been migrants or the children and grandchildren of migrants' (Pesman 19), yet through the necessary but necessarily implausible transformation of settler claims that 'we were here first' into claims that 'we were always here' (Garbutt, The Locals 203), migrants are permanently displaced as 'new Australians', while settler Australians once again replace Indigenous Australians in their originary status.

However, even if the settler's 'backward glance [is] one of rejection' (Pesman 19) - as evident in characterisations of Australia as an egalitarian and classless society in opposition to 'Old England', for example - (Veracini, 'Historylessness' 271) - 'part of our attention has always been fixed somewhere else' (Pesman 19); the persistently unsettling awareness of a pre-existent 'home' elsewhere renders settler Australia a 'haunted' place (Porter), even for ostensibly settled settlers. While within the 'clearing' of terra nullius incognita 'Anglo-Celtic migrants show up as colonists, then settlers, and eventually as locals' so that their dynamic and transitive history of migration 'becomes sedentary, not migratory', the settler psyche nevertheless finds itself 'haunted by the place left behind' (Garbutt, The Locals 207). Despite the obvious linguistic implications of the language of settlement - which attempts to make permanent the inherently transitorysettled settler Australia might therefore be more appropriately understood as an uncanny site of exile and travel in and of itself.

Offord and Haebich define exile in terms of 'the experience of uncertainty and insecurity, and a consequential expression of logic that is based on a search for a sense of belonging and a sense of place' (1); such a definition encapsulates precisely the settler situation of unsettled settledness we have attempted to articulate above. As Levitus suggests, settler Australians 
do not have the benefit of many centuries of living in one place; but a relationship [to the land] nevertheless [exists] based on the diverse experiences of travel and exile. It [is] a transitory relationship to place and the landscape ... coupled with a yearning to belong. (Cited in Read, Belonging 4)

Despite compulsive attempts to the contrary, settler Australians have consequently experienced their historical and geographical circumstances in terms of movement, constructing their identities through an inherently transitory disposition within which the tensions Levitus identifies - that is, between a yearning to belong and an equally compelling yearning to escaperemain intractable.

In Musgrove's description, the 'travelling subject, wavering between two worlds, is by no means the self-assured colonist; rather, that subject is poised to split and unravel ... in a fundamentally reflexive confrontation with the unsustainable values of "home"" (39). Here, Musgrove might as well be addressing the settler as the traveller; both waver - or find themselves caught - within the liminal in-between zone separating two (or more) worlds, constantly haunted by the spectre of 'home' while comfortably at home nowhere. As Musgrove continues, the 'traveller's action of wavering between worlds is potentially annihilating ... [it is] underscored by the anxious sense that to travel is to "be nowhere"" (32). Settler Australians continuously and compulsively shift between worlds; between various potential homelands (here, elsewhere, nowhere) as well as between self-constructed narratives of history and identity and the reality of settler-colonial circumstances; between White Australia on the one hand and the Reality (Hage) of Indigenous sovereignty on the other. To some extent, then, to inhabit the uncertain identity of the settler Australian is to find oneself 'nowhere'; if travellers experience acute - and potentially annihilatingunsettlement and uncertainty in the way that we suggest settler Australians do at 'home', then the continent itself can indeed be conceived as a site of travel.

For settler Australians, travel consequently involves an additional(ly) unsettling duality; when settler Australians travel, they move away from their already ambivalent physical and metaphysical location in Australia into equally ambivalent locations elsewhere, arguably only amplifying their already unsettled state; travel therefore functions to compound rather than relieve the settler experience of what Gelder and Jacobs have termed the 'uncanny' (23). In their analysis, 'an "uncanny" experience may occur when one's home is rendered ... unfamiliar; one has the experience ... of being in place and "out of place" simultaneously' (23). This feeling epitomises the settler's experience of unsettlement in contemporary Australia as we have described it, yet the uncanny works both ways; within the context of settler-colonial Australia as a site of travel itself, but also and simultaneously in the context of returning 
'home'. As Christou has argued - although in another cultural context-upon return the "possibilities of being "in exile" while "at home" ... convey feelings of estrangement from the homeland that returnees longed to return to' (125). There can, in other words, be no going back; settlers have become - as they always intended themselves to be-settled in their unsettled situatedness as settler Australians. Through the complex linguistic and historical processes outlined above by means of which their pre-historic connections with another 'home' elsewhere have been dissembled and disavowed, the settler has left themselves stranded in a literal and symbolic 'no man's land' without any home at all.

Returnees' simultaneous exile and 'at-home-ness' within both contemporary and historical 'homelands' can consequently be conceived as an uncanny experience; to be a settler Australian at this time is to find oneself confined within a global uncanny sphere; both at home and not at home on the continent; both at home and not at home elsewhere. Travel cannot, therefore, offer an antidote to unsettledness, for it embodies the uncanny in itself. Yet while settler Australia exists as a site of travel and exile, travel also appears to the unsettled settler as a potential means of escape. In Pesman's understanding, '[h]ome for migrants is two places, that of domicile and present loyalty and that of family origins, traditions and history' (19); in ours, home for settlers is no place at all. And yet in defiance of our analysis, the migrants' 'desire to make a return journey ... to visit relatives and to reconnect to origins ... [which] has fuelled much of Australian travel, first to Europe and now to anywhere in the world' (19) persists amongst settler Australians - at least amongst those of Anglo-Celtic origins or descent - even today, in the form of the ritualistic pilgrimage 'home' to England.

\section{Travel and 'Home'}

Travel and movement have comprised central components of the historical and contemporary experiences of all three agencies existing within the triangular dialectics of Australian settler colonialism, settlers, migrants and Indigenous Australians, throughout each of their separate and entangled histories; settler Australians have arguably existed in what we have attempted to articulate as an interminable site of travel since the time of first arrival, while migrants have only more recently begun to travel home under the sanction of a newly permissive settler society emerging from the 1970s onwards (Haebich); Indigenous Australians possess their own history and modality of movement (Pesman, White and Walker ix). For settlers in particular, however, the notion of returning 'home' to England has persisted as a coveted and exonerated form of social capital in a relatively consistent and continuous manner since the time 
of first 'settlement'; as Alomes suggests, ever 'since convicts [were] transported ... the return to Britain [has] been culturally important ... a natural inversion of the original banishment of convict exile or ... colonial separation' (2).

Writing in 1913, Alice Rosmon noted that 'the average Australian girl cherishes an ambition to come to London' (cited in Woollacott 1003), an ambition that has continued into the present. Despite the 'change in the direction of the colonial gaze' away from 'Home' in England and back towards the place in which settlers find themselves residing from the late 1960s onwards (Arthur 30), as recently as 2003 Inkson and Myers found that because Australia is 'geographically isolated from the "mother country" ... Every year, tens of thousands of young Australians ... make their pilgrimage to London ... [as] a rite of passage, a symbol of adulthood, a social norm, a source of pride' (171). It is our contention that this compulsion as it has manifested amongst settler Australians in the late or 'liquid' modern period (Bauman, Liquid Times) has been driven by the complex interplay of three specifically contemporary influences: firstly, the increasing availability and acceptance of aviation as a mode of travel; secondly, the deterritorialisation and destabilisation of formerly - at least relatively - stable identities; and finally, the emergence of an active and agentive Indigenous presence within Australian historiography and consequently settler consciousness.

To a certain extent the continuation of the phenomenon of returning 'home' beyond the period in which England has been legitimately, or acceptably, referred to as such amongst Australians of Anglo-Celtic origins or descent may well be attributed to the broader global 'democratisation of travel' which has occurred over at least the last 20 years (Pesman 26), in which 'there has ... been a transition from aviation being a luxury form of mobility for the wealthy few to being a self-evident and often cheap means of mass transportation for large parts of society in industrialized countries' (Gössling, Ceron and Dubois 132). While the degree to which the dramatic increases in global air travel represent a process of increasing democratisation rather than stratification under what Bauman has termed 'glocalisation' - within which '[s]ome inhabit the globe [while] others are chained to place' ('On Glocalization' 45) - must be questioned (Davidson; Gössling, Ceron and Dubois; Urry), it remains the case, at least for many members of the settler Australian Anglo aristocracy, that the increasing availability and affordability of air travel has functioned as an important enabler of ancestral (re)visitation.

Further, the ever-increasing influences of globalising processes within what Bauman has termed 'liquid modernity' (Liquid Times) have arguably engendered what Guibernau has described as a form of 'ontological insecurity' (134). While the potential responses to this global state of unsettlement are multiple, Richards and Wilson identify 'growing numbers of people ... reacting to the alienation of modern society by adopting the lifestyle of the backpacker' (3). While 
the typically monadic (Davidson 49-50) disposition of the modern nomadism Richards and Wilson describe is qualitatively different than that of the ancestral journeying we are concerned with, for many-and not only settlers - the opportunity to travel and consequently the opportunity and impetus to travel home has indeed arisen at the point of juncture between the dual influences of hypermobility (Adams) and destabilisation characteristic of globalised late modernity. This mode of travel may well, as Haebich suggests, constitute 'a nostalgic reaction against the globalising world as people search for "fixity" in a placeless world where everywhere and nowhere and even movement itself can be space/place, safe/perilous and home/exile' (202).

However, for settlers in particular, a third factor has arisen as an impetus towards traveling 'home'; that is, the progressive dismantling of the 'great Australian silence' - the 'cult of forgetfulness practiced on a national scale' correctly identified by Stanner as a 'structural' feature of settler Australian historiography (189) - from the late 1960s onwards (Veracini, 'A Prehistory of Australia's History Wars'). In the process of uncovering an active and agentive Indigenous presence within Australian historiography and therefore settler consciousness - or, rather, progressively reversing the impossible necessity of its historical repression (Veracini, 'Historylessness' 279) — critical and polyphonic histories have further challenged and destabilised settler claims to settled-and therefore settler-ness (Garbutt, The Locals 202). The (re)emergence of a sovereign indigenous presence within settler history undermines the 'founding forgetting' so integral to the settler's self-construction as a settler; the double effacement of history is consequently rendered ineffectual and the settler's own history of migration simultaneously (re)emerges; double vision returns and the Default Country consequently (re)appears. The settler imperative to travel "home" thus materialises as a potential and attractive means of further 'denial and avoidance' (Haebich 200), especially in light of the specific challenges to settler sovereignty instantiated by the High Court's Mabo No. 2 and Wik decisions.

Pyne recounts George Bernard Shaw's memorable description of Australians travelling 'home' to England as follows

'you Australasians are extraordinary ... Every year, thousands of you ... journey to see an inferior country which you persist in calling Home in spite of the fact that its people ignore you and are scarcely aware of your existence.' Make Australia your home, he admonished. Stay. Settle. (315)

While it may be both understandable and reasonable for settler Australians to maintain close contemporary connections to England and other homelands, these connections can be read as reflecting an inherently outward-looking disposition; as Diamond notes, 'most Australians don't depend on or really live in the Australian environment: they live instead in one of those five big cities ... 
connected to the outside world, rather than to the Australian landscape' (388). This disposition is motivated by an underlying sense of settler unsettlement and the resultant imperatives and exigencies towards modes and methods of escape, the persistence of such connections functions to prohibit attainment of the specific objective urged by Shaw; that is, to settle, to develop a substantive sense of settledness amongst the settler population in and with the place it finds itself historically and geographically located. Consequently, while the settler's necessarily pre-existent historical connection to another place is seized upon as a potential source of alleviation for their persistently unsettled state, in reality such a move functions to obfuscate any requirement for them to address the underlying causes of their predicament.

Of more immediate and pressing concern, however, are the significant environmental implications arising from the ongoing maintenance of these connections through incessant and unquestioning air travel, since air travel seriously compounds ecological issues; it is a highly polluting mode of transport (Daley; Gössling and Upham). Given that the growth of the aviation industry is proceeding apace in a world that requires drastic and immediate reductions in greenhouse gas emissions if it is to survive in any recognisable or anthropologically inhabitable state, the imperatives for settler Australians to settle are becoming increasingly and urgently important.

\section{Flying into Climate Change}

In a world where greenhouse gas emissions must be lowered-and even, it now appears, reversed (Rigby) - if life on earth as we know it is to survive into the future, any industry whose emissions are slated to grow, as are those of the aviation industry, should be regarded as highly problematic, even dangerous. As Gössling et al. suggest, while '[t]he contribution of aviation to climate change is, with a global share of just 2 per cent of emissions of $\mathrm{CO} 2 \ldots$ often regarded as negligible', this (mis)perception 'ignores ... the current and expected growth in air traffic, as well as its sociocultural drivers. Aviation is a rapidly growing sector, with annual passenger growth forecasts of 4.9 per cent in the coming 20 years' (131). Further to the corresponding increases in the overall emissions of this already emissions-intensive industry, it should be emphasised that aviation is singled out by those concerned by climate change, over and above other admittedly ecologically damaging forms of transport such as driving, because it is the altitude at which emissions are released, not simply the emissions themselves, that causes so much destruction (see Daley; Gössling). As the Intergovernmental Panel on Climate Chance (IPCC) has determined, the overall warming effect of aircraft emissions are around 2.7 times greater than 'the release of fossil carbon alone' due to the altitude at which they are 
released (Intergovernmental Panel on Climate Change). Gössling and Upham conclude that 'aviation is without a doubt significant in terms of climate change ... because of the comparably expensive options for emissions reductions in this sector, the rapid growth of air travellers, as well as its sociocultural and economic importance' (13).

This situates flying as a particularly problematic form of transport from an environmental point of view compared to other modes or methods of transportation and explains why overland travel, in most cases, is less environmentally damaging than the equivalent flight. However, seeking to replace flight with alternative, land-based methods is also problematic; as Monbiot points out,

[n]ew fuel consumption figures for both fast passenger ships and ultra high-speed trains suggest that their carbon emissions are comparable to those of planes ... What all this means is that if we want to stop the planet from cooking, we will simply have to stop travelling at the kind of speeds that planes permit. ('We Are All Killers')

Despite this uncomfortable yet unavoidable reality, amongst those in wealthy, industrialised societies, flying - as well as the underlying cultural imperative of entitled hypermobility - is rarely positioned as a choice. Nor is it discussed in terms of its social justice implications and contribution to the perpetuation of existing inequalities, even though these two characteristics are of fundamental importance to any consideration of aviation.

With regard to the former, we are now living in an era defined by travel and, more specifically, travel by aviation (Gössling and Upham). Flying is an assumed and unquestioned mode of transport for many journeys, particularly in Australia, where Blainey's 'tyranny of distance' engenders an especially positive attitude towards both domestic and international travel (Westerhausen 14). The rate of growth in travel in general and aviation in particular is simultaneously manifesting and enabling a global understanding of corporeal movement as a positive and desirable part of life; the more we travel, the more fundamentally travel becomes an intrinsic element of existence, viewed as a basic human right akin to attaining food, shelter and work. This is, of course, privileged reasoning; the very concept of leisure travel, or of air travel as an entitlement rather than a luxury, is largely a Western construct; '[i]mplicit in [our] culture is the idea that one is both entitled to travel and should travel. It ought to be an essential part of one's life and is a fundamental human right' (Urry 257). However, it is also important to note that the developing middle-classes in China and India will see more and more people worldwide slated to partake in regular flying for pleasure and work (Gössling and Upham 9), with correspondingly detrimental environmental consequences to follow. 
Yet despite a growing awareness of climate change, travel by aviation remains a taken-for-granted aspect of contemporary existence; even when it is conceived as a matter of choice, the possibility of choosing not to fly is inevitably construed as either implausible or irrelevant. While the creator of the travel writing empire Rough Guides, for example, is concerned about the aviation industry's impact on the environment, he simultaneously feels comfortable stating that 'I very much respect the purist attitudes of those who say they will never fly again, but it's totally unrealistic to expect the majority to do the same' (Hill); for him, the very possibility of choosing not to fly is dismissed in the same moment as it appears.

In a similarly obfuscating move, Hickman is able to admit that in England '[i] t seems ... we, as a nation that avidly consumes cheap flights, do indeed face a choice', yet proceeds to position this choice as arising between the competing options of continuing to "partake in ... what the industry describes as "nonessential" travel' or starting to 'ration this habit, even if others elsewhere in the world quite understandably will be quick to take our place on the plane' (our emphasis). Here, travel, especially of the 'non-essential' kind, is constructed as an actual and even conceivable choice. Yet in Hickman's self-justifying position, it is the willingness of others to take one's place and thereby negate any positive impact such an admittedly difficult choice might possess, which renders the choice itself irrelevant. This echoes arguments employed to such great effect in the Australian context against the idea of taking legislative action to curb our emissions: if other countries, especially China and India, aren't willing to follow suit-despite increasing evidence that that is precisely what they are already doing (Garnaut, The Garnaut Review 2011) - then why should we 'act first' and condemn ourselves to 'competitive disadvantage'?

Monbiot notes lamentingly that the problems of flying are

now broadly understood by almost everyone I meet. But it has had no impact whatever on their behaviour. When I challenge my friends about their planned weekend in Rome or their holiday in Florida, they respond with a strange, distant smile and avert their eyes ... The moral dissonance is deafening. ('We Are All Killers')

However, 'our' (wealthy, Western) cultural positioning of flying as a basic human entitlement remains highly problematic not only in its contribution to increases in global emissions in general, but also to the increasingly recognised relationship between climate change and social justice more specifically (Davidson; Monbiot 'We Are All Killers'; Moss; Plumwood Environmental Culture; Urry). As a result of their disproportionate and disproportionately distributed contribution to the manifestation of anthropogenic climate change, aviation and other emissions-intensive modes of transport impinge upon the actual human rights of those who will be most affected by climatic shifts and 
natural disasters, mainly those in the so-called 'third' and 'fourth' worlds; that is, citizens of disadvantaged, 'less-developed' nations and disadvantaged, often indigenous, peoples in 'developed' nations ('The Language of Foreign Affairs').

Climate change is occurring as a result of the affluent lifestyles of a small proportion of the world's population; in relation to the impacts of aviation in particular, 'it can be estimated that only about 2-3 per cent of the world's population fly in between any two countries over one consecutive year, indicating that participation in air travel is highly unequally distributed on a global scale' (Gössling, Ceron and Dubois 131). Even within industrialised societies, it is only 'a minority of highly mobile individuals who account for a large share of the overall kilometres travelled' (131). Yet the actions of this select few will negatively impact upon the many; as Monbiot articulates it, '[s]ome 92 million Bangladeshis could be driven out of their homes this century, in order that we can still go shopping in New York. Flying kills. We all know it, and we all do it' ('We Are All Killers').

\section{The Ecological Implications of Unsettled Settlers}

As Lines has argued,

[i]n 200 years European technology, warfare, culture and political economy have swept across the Australian landscape as an expression of manifest destiny, changing forever the face of the land. Nowhere else on earth have so few people pauperised such a large proportion of the world's surface in such a brief period of time. (12-13)

It is difficult to imagine a more severe disjunction between epistemological construction and ontological experience than one which has allowed such a disturbing reality to eventuate. However, the relationships between European Enlightenment epistemology and colonisation, as well as the implications of both the precepts and products of this system of thought for Australian peoples and ecologies, have been more than adequately explicated by others elsewhere (see, for example, Carter; Gascoigne; Griffiths; Langton, 'The European Construction of Wilderness'; Langton, 'Science Fictions'; Lines; Moran; Plumwood, Environmental Culture; Reynolds, The Law of the Land; Rigby; Rose, Reports From a Wild Country; Suchet; Wolfe, 'On Being Woken Up'). We are concerned specifically with the ecological implications arising from the persistently unsettled nature of the settler situation in 'Australia' as a site of travel and exile; it is our central contention that the cultural and ecological consequences of allowing this situation to continue into an already environmentally altered future will be 
devastating, not only for settlers themselves but also for their national migrant and indigenous cohabitants. And here there emerges yet another implication of 'exile', for as Hamilton notes of our future in a climatically altered world, for 'many, only by moving will they survive' (204).

In settler colonial Australia, the ecological issues we will and have already arguably begun to confront as a result of the anthropogenic climate change to which our flying habits - amongst other, multiple, manifestations of our situation as unsettled settlers - have contributed, are concerning, even dire. Importantly, as the original Garnaut Climate Change Review suggested, Australia

has a larger interest in effective global mitigation [of climate change] than any other developed country, because it is already a country of climate extremes, because of its geographic location in relation to shifts in global climate, and because it is located in a region of vulnerable developing countries. (Garnaut, 'Update Paper 2' 5)

Yet while there has been at least some segment of the settler Australian population for whom the decimation and degradation of the Australian environment has been of concern for as long as its exploitation has been systematically and exponentially occurring - that is, ever since first 'settlement' (Bonyhady)Australia remains one of the world's highest per capita emitters and continues to be 'a drag on the global mitigation effort in contradiction to its own strong national interest in effective global mitigation' (Garnaut, 'Update Paper 2' 25). It is our suggestion that this paradoxical and fundamentally irrational situation - in the sense of acting precisely against one's own interests - constitutes a consequence of the state of anxious exile and unsettlement which persists as a structural feature of settler Australian culture, manifest in the extent to which Australians remain 'outward-looking', historically, culturally and geographically.

\section{Settling Settler Australia}

Arthur notes that "[t]o settle' is defined in Australian English as: 'to settle (a place) with non-Aboriginal inhabitants and secondly to establish oneself, esp. as a farmer, on land not previously occupied by non-Aboriginal inhabitants' (38), yet the term also extends to incorporate more productive possibilities applicable to the Australian settler colonial context. Here we turn - albeit ironicallyback to the 'mother country' for authoritative affirmation, adopting the Oxford English Dictionary definition in place of the Australian National Dictionary definition as cited above, where the term includes the potential to 'resolve or reach an agreement or decision about (an argument or problem) ... [to] adopt a more steady or secure style of life ... [to] become or make calmer or quieter ... [to] begin to feel comfortable in a new situation ... [and, importantly, to] pay 
(a debt or account)' (Soanes and Stevenson). While many of these implications have been falsely applied within the Australian lexicon to discursively imagine and enact the very disavowal of indigenous sovereignty and even existence we are seeking to problematise and overturn - by imagining and maintaining the myth of 'peaceful settlement' in the outright absence of any form of settlement, legitimate or otherwise - they simultaneously possess the potential to imagine and enact a different future in which settler Australians find themselves able to settle; firstly with Indigenous Australians and, secondly, with Australian lands.

In keeping with our epistemological inheritance, we will attempt to outline our conclusion in doubles. Firstly, in our conception, settler Australians find themselves existing in a permanent state of unsettlement as a result of their illegitimate foundations and the double effacement integral to their own selfconstruction - the effacement involved in their continuing attempts to displace and replace the pre-existing, sovereign indigenous presence on the one hand and the corresponding effacement of their own migratory histories on the other. Secondly, as a consequence of this persistent state of unsettlement, settlers possess an inherently outward-looking historical, cultural and geographical disposition which perpetuates both settler degradation of the Australian environment and their disproportionate contribution to climate change, apparent in the predictably - dual imperatives of denying the realities of the lands in which they live and simultaneously seeking escape through travel and hypermobility. The imperatives, exigencies and implications arising as a result of this disposition manifest themselves in further perpetuation of settler unsettlement and anxiety, leading to our conception of Australia as a transitory space of exile and travel in and of itself. Within this unsettled and unsettling space, settlers find themselves compelled to look forwards, towards an admittedly unattainable future in which they have superseded Indigenous Australians in their direct connection with the Australian lands while compulsively looking backwards over their shoulder towards the Default Country in the hope of (re)locating and (re)constructing the historical inheritance they inadvertently disavowed in their initial act of 'founding forgetting'.

However, it seems self-evident from this reconstruction of the history of Australian 'settlement' that settlers must first turn backwards in order to move forwards; under the urgent imperatives of imminent ecological destruction and anthropogenic climate change, settlers must avert their inherently exilic gaze from their pre-histories at 'home' in the Default Country to confront the historical, cultural and geographical realities of the lands in which they live. In doing so, there must initially and inevitably occur a fundamental recognition of the realities of settler colonisation and its outcomes for Australian lands and peoples, including for settlers themselves. In particular, a correction in the imagined yet impossible necessity of displacing and replacing Indigenous 
Australians in their connection with Australian lands must be superseded by a mode of dialogical openness to the opportunities, both ecological and cultural, afforded by the continuation of this connection. In this sense, climate change may be conceived as offering settler Australians an opportunity to finally settle; for while it remains the case that 'ecoharms' are currently - and will continue to be-as unequally and unevenly distributed as other forms of harm in a society characterised by remoteness (Plumwood, Environmental Culture 85), in the current climate all Australians find themselves with something to lose. Further, while Mabo and Wik ultimately failed to deliver the recognition of and reconciliation with Indigenous Australians many had hoped for, all Australians not only have something to lose but something to gain by opening themselves to the histories of the continent on which they live as a necessary precursor to addressing — or at least adapting to - imminent climate change.

However, as Greenblatt rightly argues,

[t]here is no going back to the fantasy that once upon a time there were settled, coherent, and perfectly integrated ... communities ... [w] need to understand colonization, exile, emigration, wandering, contamination, and unintended consequences, along with the fierce compulsions of greed, longing, and restlessness, for it is these disruptive forces that principally shape the history and diffusion of identity. (2)

In advocating the reorientation of the settler gaze back towards the histories and realities of the continent on which the settler exists, we are not proposing a turn away from the future or, indeed, away from the outside world; on the contrary, we posit such a reorientation as a prerequisite for the possibility of imagining and engaging with a positive and attainable future and locatedness instead of the double dissembling and disavowal we conceive as characteristic of contemporary settler existence.

With regard to aviation specifically as both cause and symptom of the present state of settler unsettlement, the possibility of grounding flight is most often countered - outside the forms of outright or underhanded dismissal as outlined above - by the notion that to limit travel is to manifest cultural devolution, to undo the positive 'progress' of modernity. The fear here is that becoming grounded will reduce our lives, consigning them to some imagined, static, preglobalised state. Aside from the myriad difficulties inherent in the alternativeenvironmental destruction - the fundamental problem of the assertion remains that there is no going back. The increasing availability and accessibility of internet and communications technologies generates the possibility for a potential grounded culture emerging apart from those of the past, yet in addition to the inadequacy of these technologies in replicating current modes of co-presence (Urry), they are not themselves without significant ecological implications. 
In Australia, a 2010 report by Connection Research determined that 'ICT is responsible for nearly 2.7 percent of Australia's total carbon emissions ... [and] is directly responsible for more than 7 per cent of all electricity generated in Australia' (256), while in the same year the annual carbon footprint of the Internet was estimated as equivalent to 'every person in the UK flying to America and back twice over' (Clark and Berners-Lee).

Consequently, while in the potentially emergent world of virtual interconnectivity we could conceivably remain linked-in ever increasing capacities - to the outside world, even as our corporeal selves remained in place, it seems, as Monbiot suggests, that what may be required for the mitigation of anthropogenic climate change - or at least a reduction in its effects - is simply self-imposed restraint. As he has suggested with regard to aviation, this means

the end of distant foreign holidays, unless you are prepared to take a long time getting there ... that business meetings must take place over the internet or by means of video conferences ... that transcontinental journeys must be made by train or coach ... that journeys around the world must be reserved for visiting the people you love, and that they will require both slow travel and the saving up of carbon rations ... the end of shopping trips to New York, parties in Ibiza, second homes in Tuscany ... unless you believe that these activities are worth the sacrifice of the biosphere and the lives of the poor. ('On the Flightpath to Global Meltdown')

However, nor does the adoption by settler Australians of an 'ethics of location' (Garbutt, 'Towards an Ethic of Location'; Garbutt, The Locals) aiming towards the recognition of and reconciliation with Indigenous Australians and Australian lands through a dialogical disposition founded on understandings of interconnectivity and inclusivity entail turning away from the outside world. To do so would be to simply (re)perpetuate the epistemic hyperseparations so deeply implicated in the issues we have been discussing (Plumwood, Environmental Culture) in much the same way as contemporary preservationist environmental discourse functions to reverse rather than disrupt the dualisms it ostensibly rejects (Suchet 146). Neither does such a disposition entail an uncritical adoption of a 'Heideggerian singularity of focus [which] legitimates a narrowing of place relationship to a special place, in a way that supports a concept of the home property of a (national) self that is strongly set apart from and above other places, in terms of care and priority' (Plumwood, 'Shadow Places' 144). Rather, what is required is the emergence of a non-possessive conception of belonging capable of encompassing dialogue, relationality and concepts of sharing - particularly as pertaining to present understandings of sovereignty (Chartrand; Fleras; Tully) - a rethinking of the very notion of belonging so persistently problematic in the settler colonial context (Read, Returning to Nothing; Read, Belonging). 
This reconceptualisation would not prohibit travel in and of itself-even travel by aviation - but would rather function to render the structural settlercolonial imperatives towards the compulsively monadic and escapist mode of travel we have identified amongst settler Australians effectively redundant. The reorientation of settler consciousness away from haunting images of 'Home' and towards the multiple, complex and divergent histories of the place in which they live, along with the removal of the imperative towards escape through substantive negotiated settlement, would enable the emergence of a mode of journeying (Mathews; Plumwood, Environmental Culture) characterised by dialogical and communicative openness towards the world.

What we are proposing, then, is an 'ethics of location' (Garbutt, 'Towards an Ethic of Location'; Garbutt, The Locals) or 'ethics of place' (Plumwood, 'Decolonising Australian Gardens'; Plumwood, 'Shadow Places') arising within an active and collaborative 'ethics for decolonisation' based on principles of situatedness and openness as explicated and advocated by Rose (Reports From a Wild Country). Such an ethics, as Rose has articulated, possesses particular relevance to the settler situation in its rejection of the notions of 'homogenisation, appropriation, objectification, and manipulation' (189) so characteristic of settler societies. Further - and of obvious relevance to the preceding discussionin Rose's conception an ethics for decolonisation necessarily 'includes our moral engagements with our past and future, and with our ecosystems' (189). The similarities between the inclusively situated settler disposition we are advocating and the interconnective and relational understandings inherent within Indigenous ontologies as articulated by Graham, Martin and Rose (Nourishing Terrains) amongst others are clear, yet in consideration of settler Australians' historical appropriation of Indigenous lands and identities under the settler colonial imperatives towards the displacement and replacement of the pre-existing indigenous presence, we must be careful in proceeding. To borrow from Arendt, alongside Rose and Garbutt, what we therefore propose as a potential means of finally and substantively settling settler Australia is very simple: it is nothing more than to think what we are doing' (5) in place.

Alice Robinson lectures in the Bachelor of Writing and Publishing at NMIT in Melbourne. Published widely in print and online, she is a writer of fiction, literary essays and reviews, and co-editor of Australian literary journal Southpaw. Nearing completion, her $\mathrm{PhD}$ research consists of a novel and exegesis that together explore attitudes to place and landscape in Australia. Specifically, Alice is interested in the way that settler Australian cultures understand and relate to the Australian landscape, asking what the implications of these understandings and their ecological impacts may be for climate change. 
Dan Tout is an Honours candidate at Swinburne University of Technology, where he is researching the structural influences of settler colonialism on the development of Australian nationalism. For the past three years he has also worked as a research assistant at Victoria University in the School of Language \& Learning.

\section{Works Cited}

Adams, John. 'The Social Implications of Hypermobility: Speculations About the Social Consequences of the OECD Scenarios for Environmentally Sustainable Transport and Business-as-Usual Trend Projections.' Organisation for Economic Co-operation and Development (OECD). Paris, France. 1999. 95-134.

Alomes, Stephen. When London Calls: The Expatriation of Australian Creative Artists to Britain. Cambridge, UK: Cambridge UP, 1999.

Arendt, Hannah. The Human Condition. 2nd ed. Chicago, IL: U of Chicago P, 1998.

Arthur, J. M. The Default Country: A Lexical Cartography of Twentieth-Century Australia. Sydney, NSW: U of New South Wales P, 2003.

Ashcroft, Bill, Gareth Griffiths, and Helen Tiffin. The Empire Writes Back: Theory and Practice in Post-Colonial Literatures. 2nd ed. London \& New York: Routledge, 2002.

Australian Government Department of Foreign Affairs \& Trade (DFAT). 'About Australia: Australia's Environment At a Glance.' Australian Government Department of Foreign Affairs \& Trade. 2008. 29 April 2011. <http://www. dfat.gov.au/facts/env_glance.html>

Bauman, Zygmunt. 'On Glocalization: Or Globalization for Some, Localization for Some Others.' Thesis Eleven 54 (1998): 37-49.

-. Liquid Times: Living in an Age of Uncertainty. Cambridge, UK: Polity Press, 2007.

Blainey, Geoffrey. The Tyranny of Distance: How Distance Shaped Australia's History. Revised ed. Melbourne, VIC: Sun Books, 1983.

Bonyhady, Tim. The Colonial Earth. Carlton, VIC: Miegunyah Press, 2000.

Carter, Paul L. A. H. The Road to Botany Bay: An Essay in Spatial History. London, UK: Faber and Faber, 1987. 
Chartrand, Paul. 'Reconciling Indigenous Peoples' Sovereignty and State Sovereignty.' Australian Institute for Aboriginal and Torres Strait Islander Studies. Canberra, ACT. 2009.

Christou, Anastasia. Narratives of Place, Culture and Identity: A Second Generation Greek-American's Return Home. Amsterdam, The Netherlands: Amsterdam UP, 2006.

Clark, Duncan, and Mike Berners-Lee. 'What's the Carbon Footprint of... The Internet?' The Guardian 12 August 2010: n. pag. 6 March 2012.

Connection Research. 'Carbon and Computers in Australia: The Energy Consumption and Carbon Footprint of ICT Usage in Australia in 2010.' Australian Computer Society. Sydney, NSW. 2010.

Daley, Ben. Air Transport and the Environment. Farnham, UK: Ashgate, 2010.

Davidson, Robyn. 'No Fixed Address: Nomads and the Fate of the Planet.' Quarterly Essay 24 (2006): 1-53.

Diamond, Jared M. Collapse: How Societies Choose to Fail Or Survive. Camberwell, VIC: Penguin Group, 2005.

Fleras, Augie. 'Politicising Indigeneity: Ethno-Politics in White Settler Dominions.' Indigenous Peoples' Rights in Australia, Canada, and New Zealand. Ed. Paul Havemann. Oxford, UK: Oxford UP, 1999. 187-234.

Garbutt, Rob. 'Towards an Ethic of Location.' Landscapes of Exile: Once Perilous, Now Safe. Eds. Anna Haebich, and Baden Offord. Bern, Switzerland: Peter Lang, 2008. 175-92.

- The Locals: Identity, Place and Belonging in Australia and Beyond. Bern, Switzerland: Peter Lang, 2011.

Garnaut, Ross. The Garnaut Climate Change Review: Final Report. Cambridge, UK: Cambridge UP, 2008.

- The Garnaut Review 2011: Australia in the Global Response to Climate Change. Cambridge, UK: Cambridge UP, 2011.

- 'Update Paper 2: Progress Towards Effective Global Action on Climate Change.' Garnaut Climate Change Review-Update 2011. Canberra, ACT. 2011 .

Gascoigne, John. The Enlightenment and the Origins of European Australia. Port Melbourne, VIC: Cambridge UP, 2002. 
Gelder, Ken, and Jane M. Jacobs. Uncanny Australia: Sacredness and Identity in a Postcolonial Nation. Carlton, VIC: Melbourne UP, 1998.

Goldie, Terry. Fear and Temptation: The Image of the Indigene in Canadian, Australian, and New Zealand Literatures. Kingston, Montreal, London: McGill-Queen's UP, 1989.

Gössling, Stefan, Jean-Paul Ceron, Ghislain Dubois, and Michael C. Hall. 'Hypermobile Travellers.' Climate Change and Aviation: Issues, Challenges and Solutions. Eds. Stefan Gössling, and Paul Upham. London, UK \& Sterling, VA: Earthscan, 2009. 131-50.

Gössling, Stefan, and Paul Upham. 'Introduction.' Climate Change and Aviation: Issues, Challenges and Solutions. Eds. Stefan Gössling, and Paul Upham. London, UK \& Sterling, VA: Earthscan, 2009. 1-23.

Gössling, Stefan, and Paul Upham, eds. Climate Change and Aviation: Issues, Challenges and Solutions. London, UK \& Sterling, VA: Earthscan, 2009.

Graham, Mary. 'Some Thoughts About the Philosophical Underpinnings of Aboriginal Worldviews.' Worldviews: Global Religions, Culture, and Ecology 3.2 (1999): 105-18.

-. 'Some Thoughts About the Philosophical Underpinnings of Aboriginal Worldviews.' Australian Humanities Review 45 (2008): 181-94.

Greenblatt, Stephen. 'Cultural Mobility: An Introduction.' Cultural Mobility: A Manifesto. Eds. Stephen Greenblatt, Ines Županov, Reinhard Meyer-Kalkus, Heike Paul, Pál Nyíri, and Frederike Pannewick. Cambridge, UK: Cambridge UP, 2010. 1-23.

Griffiths, Tom. 'History and Natural History: Conservation Movements in Conflict?' The Humanities and the Australian Environment: Papers From the Australian Academy of the Humanities. Ed. D. J. Mulvaney. Canberra, ACT: Australian Academy of the Humanities, 1991. 87-109.

Guibernau, Maria Montserrat. 'Globalization, Modernity and National Identity.' Nationalisms: The Nation-State and Nationalism in the Twentieth Century. Cambridge, UK: Polity Press, 1996. 128-38.

Haebich, Anna. 'Un-Settling White Australia: The Significance of Going Home.' Landscapes of Exile: Once Perilous, Now Safe. Eds. Anna Haebich, and Baden Offord. Bern, Switzerland: Peter Lang, 2008. 193-209.

Hage, Ghassan. White Nation: Fantasies of White Supremacy in a Multicultural Society. New York, NY: Routledge, 2000. 
Hamilton, Clive. Requiem for a Species: Why We Resist the Truth About Climate Change. Crows Nest, NSW: Allen \& Unwin, 2010.

Hickman, Leo. 'Is it Ok to Fly?' The Guardian 20 May 2006: n. pag. 28 March 2011.

Hill, Amelia. 'Travel: The New Tobacco.' The Guardian 6 May 2007: n. pag. 1 March 2011.

Hodge, Bob, and Vijay Mishra. Dark Side of the Dream: Australian Literature and the Postcolonial Mind. Sydney, NSW: Allen \& Unwin, 1991.

Inkson, Kerr, and Barbara A. Myers. “The Big OE": Self-Directed Travel and Career Development.' Career Development International 8.4 (2003): 170-81.

Intergovernmental Panel on Climate Change. 'Aviation and the Global Atmosphere.' IPCC Special Reports on Climate Change, 2001. 5 March 2012. $<$ http://www.grida.no/publications/other/ipcc_sr/?src=/climate/ipcc/ aviation/064.htm>

Jupp, James, ed. The Australian People: An Encyclopedia of the Nation, Its People and Their Origins. Cambridge, UK: Cambridge UP, 2001.

Jupp, James. 'The Australian People.' Sydney Papers 14.1 (2002): 48-55.

Langton, Marcia. 'The European Construction of Wilderness.' Wilderness News (1996): 16-17.

-. 'Science Fictions.' Burning Questions: Emerging Environmental Issues for Indigenous Peoples in Northern Australia. Darwin, NT: Centre for Indigenous Natural and Cultural Resource Management, Northern Territory University, 1998. 18-37.

Language of Foreign Affairs, The. Darby, PA: DIANE Publishing Company, 1987.

Lines, William J. Taming the Great South Land: A History of the Conquest of Nature in Australia. North Sydney, NSW: Allen \& Unwin, 1991.

Lloyd, Genevieve. 'No One's Land: Australia and the Philosophical Imagination.' Hypatia 15.2 (2000): 26-39.

Locke, John. 'Two Treatises of Government.' The Works of John Locke. London, UK: Thomas Tegg, 1823. 5-216.

Mackellar, Dorothea. My Country. 1908. 
Martin, Karen. 'Ways of Knowing, Being and Doing: A Theoretical Framework and Methods for Indigenous and Indigenist Re-Search.' Journal of Australian Studies 76 (2003): 203-14.

Mathews, Freya. Reinhabiting Reality: Towards a Recovery of Culture. Sydney, NSW: U of New South Wales P, 2005.

Melbourne Water. 'Drought Management.' 6 March 2012. <http://www. melbournewater.com.au/content/water_conservation/drought_ management/drought_management.asp $>$

Monbiot, George. 'On the Flight Path to Global Meltdown.' The Guardian 21 September 2006: n. pag. 10 November 2010.

—. 'We Are All Killers.' George Monbiot. 2006. 22 April 2011. <http://www. monbiot.com/2006/02/28/we-are-all-killers/>

Moran, Anthony. 'As Australia Decolonizes: Indigenizing Settler Nationalism and the Challenges of Settler/Indigenous Relations.' Ethnic and Racial Studies 25.6 (2002): 1013-42.

Moss, Jeremy, ed. Climate Change and Social Justice. Carlton, VIC: Melbourne UP, 2009.

Musgrove, Brian. 'Travel and Unsettlement: Freud on Vacation.' Travel Writing and Empire: Postcolonial Theory in Transit. Ed. Steve Clark. London, UK: Zed Books, 1999. 31-44.

Offord, Baden, and Anna Haebich. 'Introduction: Landscapes of Exile- “Once Perilous, Now Safe".' Landscapes of Exile: Once Perilous, Now Safe. Eds. Anna Haebich, and Baden Offord. Bern, Switzerland: Peter Lang, 2008. 1-4.

Pesman, Ros. 'Overseas Travel of Australian Women.' La Trobe Journal 58 (1996): 19-26.

Pesman, Ros, Richard White, and David Walker, eds. The Oxford Book of Australian Travel Writing. Melbourne, VIC: Oxford UP, 1996.

Plumwood, Val. Environmental Culture: The Ecological Crisis of Reason. London \& New York: Routledge, 2002.

-. 'Decolonising Australian Gardens: Gardening and the Ethics of Place.' Australian Humanities Review 36 (2005): n. pag.

-. 'Shadow Places and the Politics of Dwelling.' Australian Humanities Review 44 (2008): 139-50. 
Porter, Dennis. Haunted Journeys: Desire and Transgression in European Travel Writing. Princeton, NJ: Princeton UP, 1991.

'Pray for Rain, Urges Howard.' The Age 22 April 2007: n. pag. 25 April 2011.

Pyne, Stephen J. Burning Bush: A Fire History of Australia. New York, NY: Holt, 1991.

Read, Peter. Returning to Nothing: The Meaning of Lost Places. Cambridge, UK: Cambridge UP, 1996.

-. Belonging: Australians, Place and Aboriginal Ownership. Cambridge, UK: Cambridge UP, 2000.

Reynolds, Henry. The Law of the Land. Melbourne, VIC: Penguin Books, 1987.

-. 'New Frontiers: Australia.' Indigenous Peoples' Rights in Australia, Canada, and New Zealand. Ed. Paul Havemann. Oxford, UK: Oxford UP, 1999. 129-40.

Richards, Greg, and Julie Wilson. 'Drifting Towards the Global Nomad.' The Global Nomad: Backpacker Travel in Theory and Practice. Eds. Greg Richards, and Julie Wilson. Clevedon, UK: Channel View Publications, 2004. 3-13.

Rigby, Kate. 'Dancing With Disaster.' Australian Humanities Review 46 (2009): 131-44.

Rose, Deborah Bird. Nourishing Terrains: Australian Aboriginal Views of Landscape and Wilderness. Canberra, ACT: Australian Heritage Commission, 1996.

-. Reports From a Wild Country: Ethics for Decolonisation. Sydney, NSW: U of New South Wales P, 2004.

Smith, Anthony D. The Ethnic Origins of Nations. Oxford, UK: Basil Blackwell Ltd, 1986.

Soanes, Catherine, and Angus Stevenson, eds. The Concise Oxford English Dictionary. 12th ed. Oxford, UK: Oxford UP, 2008.

Stanner, W. E. H. The Dreaming \& Other Essays. Melbourne, VIC: Black Inc. Agenda, 2009.

Suchet, Sandie. “Totally Wild'? Colonising Discourses, Indigenous Knowledges and Managing Wildlife.' Australian Geographer 33.2 (2002): 141-57.

Sussex, Lucy. Saltwater in the Ink: Voices From the Australian Seas. North Melbourne, VIC: Australian Scholarly Publishing, 2010. 
Tully, James. 'The Struggles of Indigenous Peoples for and of Freedom.' Political Theory and the Rights of Indigenous Peoples. Eds. Duncan Ivison, Paul Patton, and Will Sanders. Cambridge, UK: Cambridge UP, 2000. 36-59.

Urry, John. 'Mobility and Proximity.' Sociology 36.2 (2002): 255-74.

Veracini, Lorenzo. 'A Prehistory of Australia's History Wars: The Evolution of Aboriginal History During the 1970s and 1980s.' Australian Journal of Politics \& History 52.3 (2006): 439-54.

- 'Historylessness: Australia as a Settler Colonial Collective.' Postcolonial Studies 10.3 (2007): 271-85.

- Settler Colonialism: A Theoretical Overview. Basingstoke, UK: Palgrave Macmillan, 2010.

Westerhausen, Klaus. Beyond the Beach: An Ethnography of Modern Travellers in Asia. Banglamung, Thailand: White Lotus Press, 2002.

Wolfe, Patrick. 'On Being Woken Up: The Dreamtime in Anthropology and in Australian Settler Culture.' Comparative Studies in Society and History 33.2 (1991): 197-224.

- Settler Colonialism and the Transformation of Anthropology. London \& New York: Cassell, 1999.

Woollacott, Angela. "'All This is the Empire, I Told Myself": Australian Women's Voyages "Home" and the Articulation of Colonial Whiteness.' American Historical Review 102.4 (1997): 1003-29. 